\title{
The Effects of Common Vetch Grain (Vicia Satıva) on Some Blood, Rumen Parameters and Rumen Protozoa in Lambs
}

\section{Cemal BUDAĞ ${ }^{1 *}$, Evrim TAŞ ${ }^{1}$}

\begin{abstract}
ABSTACT: This study investigated the effect of different levels of common vetch (CV) grain feed on some blood and rumen parameters and rumen protozoa in lambs consuming sainfoin hay (SH). In the study two-month-old weaned, SH consumed, $36.25 \pm 2.49 \mathrm{~kg}$ average body weight (BW), twenty-four female lambs were used. Ration groups were established as follows; In the first group (C, control), $2 \%$ $\mathrm{SH}$ and $0.00 \% \mathrm{CV}$ of the lamb's live weight (LW) were adopted while in the second group, $1.25 \% \mathrm{SH}$ and $0.75 \% \mathrm{CV}$ ( CVI) and in the third group, $0.5 \% \mathrm{SH}$ and $1.50 \% \mathrm{CV}$ (CVII) were adopted. Blood and rumen fluid samples were taken twice, once at the beginning of the study and once on the 30th day of the study. Although there were statistical differences in some of the parameters investigated in the study, all blood and rumen parameters were within the normal limits specified for lambs in the literature. In this study, it was concluded that feeding the lambs that are consuming SH with CV $1.5 \%$ of their live weight did not have a negative effect and the total ration can be formed using both SH and CV.
\end{abstract}

Key Words:-Blood-parameters, lamb, protozoa, rumen, sainfoin, vetch

${ }^{1}$ Cemal BUDAĞ (Orcid ID: 0000-0003-3532-7727), Evrim Taş: (Orcid ID:0000-0001-8234-5296) Van Yüzüncü Y11 University, Faculty of Agriculture, Department of Animal Science, Van, Turkey

*Sorumlu Yazar/Corresponding Author: Cemal BUDAĞ1, e-mail: cbudag@yyu.edu.tr

This study was produced from Evrim Taş's Master's thesis.

The article was presented as a poster at the 6th National Animal Science Congress held in Erzurum on 24-26 JUNE 2009. 6. National Animal Science Congress, Book, Poster Presentation Paper 24-26 / 2009. Page 161. Erzurum

ETIKK KURUL ONAYI / ETHICS COMMITTEE APPROVAL: This study was conducted under the control of Dr. Cemal Budağ and Prof. Dr. Abuzer Taş, who possessed the "Animal Experiment Authorization Certificate" of Yüzüncü Yıl University, in 2008. Animal experiments ethics committee report was not requested at the time. has been updated due to regaining importance in their countries. 


\section{INTRODUCTION}

Food and feed production, which does not increase in parallel to population growth in the world, creates increasing biomass and an industrial raw material deficit in human and animal nutrition. It has been reported that agricultural productivity should be increased between 70 -and $110 \%$ by 2050 to cover this deficit. Accordingly, in many countries, especially in Europe, studies have been carried out to diversify and to increase the production of high-stress-resistant, high-yielding products. In many European countries, governments support the production of legumes, including common vetch, which is used successfully in soil improvement and is more resistant to aggressive climatic conditions compared to wheat (Hanbury et al. 2000; Lestingi et all. 2015; Asharf et al. 2018).

Huang et al. (2017), in a review study, have reported that common vetch grains were less expensive compared to its alternatives, rich in protein and mineral resources for livestock, it has a high digestibility and high energy content, therefore, it can be partially or solely used in the rations as an alternative to soybean, and as a sole alternative to most of the grains used in rations. Further research is needed to determine the nutritional values of common vetch and to understand its effects on various animal species (fish, poultry, pigeons, pigs, horses, cattle, sheep, goats) considering the physiological periods of the animals (young, adult, lactation period, pregnancy period). (McDonald and Copeland 1997). Common vetch species (including $V$. sativa L.) are characterized by the presence of $\gamma$-glutamyl- $\beta$-cyano-alanine (GCA) and $\beta$-cyano-L-alanine (BCA), which are toxic to monogastric animals (Huang et al. 2017; Sherasia et al. 2017). Common vetch has the potential to be an additional feed source with high energy and protein contents. It has been reported that the protein level in the structure of common vetch grain varies between 26.6 and 39.3\% in dry matter (Abreu and Bruno-Soares 1998; Eugeniusz et al. 2010; Seifdavati and Taghizadeh 2012; Mao et al. 2015; Huang et al. 2017). The metabolic energy level of common vetch grain has been reported in the range of $8.67-12.50 \mathrm{MJ} \mathrm{kg}^{-1}$ in dry matter (Huang et al. 2017).

The production of various leguminous forage crops has become widespread in the structural improvement studies of the soils that are impoverished by conventional production (Sheppard et al. 2019). Also, the fact that leguminous roughage crops synthesize higher microbial protein compared to wheat forages directs producers to produce leguminous roughage (Wilkinsa and Jones 2000). As well as the roughage production for ruminant feeding in the world, leguminous roughage remaining from leguminous crop production for both human food and animal feed originating from plant stems and leaves of grain legumes are also intensively used in rations. These products, which are of legume origin, are mostly supplemented with starch feeds such as corn and barley with high production costs and protein feeds such as soybean meal (Bruno-Soares et al. 2000; Yeheyis et al. 2004; Carbonero et al. 2011; Dejene et al. 2018).

This study was conducted to investigate the effects of using sainfoin hay as a forage source in lamb rations, and common vetch grain, as an intense feed source on some blood and rumen parameters and rumen protozoa in lambs.

\section{MATERIAL AND METHOD}

This study was carried out in Van Yüzüncü Y1l University Research and Application Farm. In this study, 24 female lambs, accustomed to consuming sainfoin hay ( $\mathrm{SH}$ ), weaned, approximately four weeks old and with an average live weight of $36.25 \pm 2.49 \mathrm{~kg}$ were used. The dry matter (DM) requirements of lambs were determined as $2 \%$ of their live weight (LW). In the control group (C) CV $0.00 \%$ and SH $2.00 \%$ of LV, in Group 1 (CVI), CV $0.75 \%$ and $\mathrm{SH} 1.25 \%$ of live weight and group 2 (CVII), CV $1.50 \%$ and $\mathrm{SH}$ as $0.50 \%$ of LW was given- exercise feeding was performed for 5 days. Then the trial 
lasted 25 days. The daily ration for each lamb was split into equal two portions and fed at 08:00 and 16: $00 \mathrm{~h}$. The mineral vitamin supplement contents of which are given in Table 3 was added to the rations at a level of $0.10 \%$ during the experiment(Table 1-2).

While feed's dry matter (DM), crude protein (CP), ether extract (EE) and crude ash CA analyzes were carried out according to AOAC (1990), acid detergent fiber (ADF) and neutral detergent fiber (NDF) analyzes were carried out in Van Soest et al. (1991) (Table 3).

Table 1. The amount of sainfoin hay and common vetch given to animals in the study

\begin{tabular}{crrrrrr}
\hline & CV $^{*}$ & SH* & CV**$^{* *}$ & SH** & CV*** $^{* *}$ SH*** \\
\hline C & 0.0 & 100 & 0.000 & 0.725 & 0.00 & 2.00 \\
CVI & 37.5 & 62.5 & 0.272 & 0.453 & 0.75 & 1.25 \\
CVII & 75.0 & 25.0 & 0.544 & 0.181 & 1.50 & 0.50 \\
\hline
\end{tabular}

* CV and SH Ratios in Ration (\%), **CV and SH amounts (grams / lamb), ***Ratio of CV and SH to Animal Weight (\%).

Table 2. Chemical composition of group feeds $(\%)^{*}$.

\begin{tabular}{lrrrrrr}
\hline & DM & CP & EE & CA & ADF & NDF \\
\hline C & 92.89 & 11.43 & 0.86 & 16.97 & 47.44 & 66.69 \\
CVI & 93.31 & 16.77 & 7.18 & 14.50 & 32.96 & 59.50 \\
CVII & 93.73 & 22.12 & 5.75 & 12.04 & 18.48 & 52.31 \\
\hline
\end{tabular}

* Vitamin mineral (Fascovite) was added to the diet at a rate of 0,10\%. $1 \mathrm{~kg}$ of Faskoviti; $1000000 \mathrm{IU}$ of vitamin A, $200000 \mathrm{IU}$ of vitamin D3, $400 \mathrm{mg}$ of vitamin E, $500 \mathrm{mg}$ of vitamin B1, $500 \mathrm{mg}$ of vitamin B2, $304 \mathrm{mg}$ of vitamin B6, $5000 \mathrm{mg}$ of Fe, $1000 \mathrm{mg}$ of Cu, $5000 \mathrm{mg}$ of Zn, $80 \mathrm{mg}$ of Mn. , $20 \mathrm{mg}$ Co, $21 \mathrm{mg} \mathrm{Se}, 9,180 \mathrm{mg} \mathrm{Mg}, 12750 \mathrm{P}, 18750 \mathrm{mg} \mathrm{Ca}$.

Table 3. Nutrient Contents of CV and SH (\%).

\begin{tabular}{lllllll}
\hline & DM & CP & EE & CA & ADF & NDF \\
\hline CV & 92.89 & 11.43 & 0.86 & 16.97 & 47.44 & 66.69 \\
SH & 94.01 & 25.68 & 0.48 & 10.39 & 8.83 & 47.51 \\
\hline
\end{tabular}

The first blood samples were collected in the morning after the study groups were formed before the animals were fed, and the second samples were collected on the 30th day of the study as in the first sample collection. For blood analysis $10 \mathrm{ml}$ blood samples were collected from each animal from the vena jugular with a cannula. After the serum was separated from the blood samples by centrifugation, the samples were kept in a cool, without light condition until analysis. In the serum samples, blood sugar (BG), total protein (TP), triglyceride (TG), blood urea nitrogen (BUN), calcium (Ca), phosphorus (P), potassium $(\mathrm{K})$, chloride $(\mathrm{Cl})$ and sodium $(\mathrm{Na})$ amount analysis were made using the modular type e Hitachi Automated Analyzer and Tokyo/Japan and Roche kits (Qing-jun at al. 2008).

The first rumen liquid samples were collected in the morning after the study groups were formed before the animals were fed, and the second samples were collected on the 30th day of the study as in the first sample collection. As was the case for blood collection, before and after the study, rumen fluid samples $(50 \mathrm{ml}$ per animal) were taken by oral rumen probe twice, one before and one after the experiment. The samples were slightly stirred to stabilize the rumen liquid, and then, the rumen liquid $\mathrm{pH}$ values were immediately measured with a digital $\mathrm{pH}$ meter. Concentrations of ammonia nitrogen in the rumen fluid was performed according to the method of Markham steam distillation (Markham, 1942). Preparation of rumen fluid for protozoa count and the number of protozoa in the rumen fluid was made according to Dehority (1984).

Descriptive statistics of the characteristics were expressed as mean and standard error. To determine whether there were differences between application groups (C, CVI, and CVII) and times (B 
and A) in terms of characteristics; Two-way ANOVA (repeated measurement on one-factor levels) was performed. To determine the different group means; Tukey multiple comparison test was used. All statistical analyses were carried out in the STATISTICA statistical package program (Winer, 1971).

\section{RESULTS AND DISCUSSION}

The nutrient contents of sainfoin hay $(\mathrm{SH})$ used as roughage in the study are as follows (Table 2); DM 92.89\%, CP 11.43\%, CF 0.86\%, CA 16.97\%, ADF 47.44\%, and NDF 66.69\%. The nutrient contents of common vetch (CV) used as grain feed are as follows; DM 94.01\%, CP 25.68\%, EE 0.48\%, CA $10.39 \%$, ADF $8.83 \%$, and NDF $47.51 \%$ (Table 3).

In thise study no differences were observed between blood serum BG, TP and TG levels in lambs consuming $\mathrm{SH}$ depend-on time and $\mathrm{CV}$ consumption $(\mathrm{P}<0.05)$. The $\mathrm{Ca}$ and $\mathrm{Cl}$ values of the groups consuming SH at the beginning of the study increased at the end of the experiment independent of the $\mathrm{CV}$ consumption $(\mathrm{P}<0.001)$, whereas the $\mathrm{P}$ values decreased over time independent of the $\mathrm{CV}$ consumption $(\mathrm{P}<0.05)$. As seen in Table 4, the blood serum BUN $(\mathrm{P}<0.001)$ and $\mathrm{K}(\mathrm{P}<0.05)$ levels decreased due to the increase in $\mathrm{CV}$ consumption and were different from the control group. A random change in the blood $\mathrm{Na}$ level depend on time and CV was observed ( $\mathrm{p}<0.05$ ), however, this change could not be explained by feed and time factors. While ruminal $\mathrm{pH}$ levels of lambs consuming SH did not change depend-on time and $\mathrm{CV}$ consumption, the rumen protozoa counts increased in all groups over time ( $\mathrm{P}<0.001$ ), but no differences were observed between the control group and $\mathrm{CV}$-consuming groups (Table 5). With the addition of $\mathrm{CV}$ to the diets of lambs consuming $\mathrm{SH}$, rumen $\mathrm{NH}_{3}-\mathrm{N}$ levels increased parallel to the increase in the $\mathrm{CV}$ ratio and found to be statistically different from the control group (P $<0.05)$.

The SH and CV nutrient contents used in this study (Table 2) were similar to the nutrients given for $\mathrm{SH}$ and $\mathrm{CV}$ in numerous similar studies, however different from the nutrients given in some other studies. It was thought that this difference was caused by the variety, cultivation and harvest conditions of the feed (Seifdavati and Taghizadeh 2012; Aufre're et al. 2013; Mao et al. 2015; Huang et al. 2017). In this study, some blood and rumen parameters obtained from animals are summarized in Tables 4 and 5.

In many studies on blood BG levels in lambs depending on different feeding conditions and age, it has been reported that blood values ranged between 50 and $144 \mathrm{mg} / \mathrm{dl}$ (El-Barody et al. 2002; Lestingi et al. 2015; Malekkhahi et al. 2015). In this study, no statistically significant differences were observed between the blood BG levels of lambs consuming SH and blood BG levels obtained after CV consumption. The results suggesting that blood BG levels were not negatively affected after vetch consumption was consistent with the literature. Lestingi et al. (2015) have reported that different leguminous grains did not affect blood BG levels and that BG levels varied between 65.4 and $70.9 \mathrm{mg} / \mathrm{dl}$. Elmali et al. (2011) have reported that the use of common vetch up to $30 \%$ instead of soy did not affect blood BG levels in lambs.

In studies conducted with legume grains, it has been reported that blood BUN values in lambs ranged between 21.24 and $25.58 \mathrm{mg} / \mathrm{dl}$ (Lestingi et al. 2015) and in sheep between 12.9 and $49.00 \mathrm{mg} / \mathrm{dl}$, and blood BUN values increased due to increased protein levels. In this study, the blood BUN values of SH and CV consuming lambs were found close to the upper limit stated in the literature and, with the increase in common vetch consumption, similar to those reported in the literature (Kohn et al. 2005), the BUN levels increased with the increase in the protein levels in the rations $(\mathrm{P}<0.05)$. In this study, it was thought that the blood BUN values of lambs were close to the upper limit since both feeds used in ration were protein-rich legumes. 
Leguminous grains have been reported to reduce blood TG levels in monogastric animals but not in ruminant animals (Kobeisy at al. 2017). The low fat levels in the structure of legume grains other than soy also lead to a decrease in blood TG levels in monogastric animals (Ouanes et al. 2011). In this study, there were no statistical differences in blood TG levels after CV addition to the rations of lambs consuming SH. This result was higher than those reported by Malekkhahi et al. (2015) in the study reporting that the ration was rich in starch $(13.6-18.8 \mathrm{~g} / \mathrm{dl})$, whereas similar to those reported by Facciolongo et al. (2014) and Mieczan and Kwiecien (2010) on their study on legumes (19.20-25.78 $\mathrm{mg} / \mathrm{dl})$. In this study, the reason for the absence of an increase in blood TG level is the absence of fat level feed source in the ration.

Lestingi et al. (2015) have reported that the use of broad bean and sweet lupins did not affect the blood TP levels and that the blood TP levels varied between 6.06 and $6.58 \mathrm{~g} \mathrm{dl}^{-1}$. Elmall et al. (2011) have reported that using 10, 20 or $30 \% \mathrm{CV}$ instead of soybean meal did not affect the blood TP levels of lambs and that blood TP levels ranged between 6.25 and $7.04 \mathrm{~g} \mathrm{dl}^{-1}$. In the present study, it was found that the use of CV and SH did not affect the blood TP levels of the lambs. Studies have reported that the

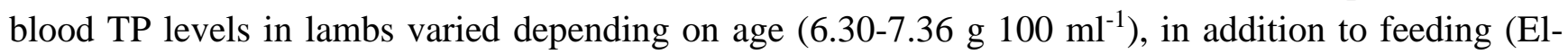
Barody et al. 2002; Bórnez et al.2009). Lestingi et al. (2015) have reported that the anti-nutritional factors in the rations increased the blood TP levels. The blood TP levels determined in the present study were found to be between the upper and lower limits of blood TP of lambs given in the literature. This was associated with the absence of stress on the immune system as a result of the degradation of the rumen antimicrobial factors in the structure of CV. In this study, the probable reason why blood TP level is close to the upper limit is that both of the feeds used in the ration are protein-rich feed.

Kaneko and Kornelius (1970) have reported the blood Ca limit values in lambs as 8.30-11.43 mg $\mathrm{dl}^{-1}$. It has been stated in the literature that race, sex, and housing conditions did not affect blood serum $\mathrm{Ca}$ level, however, the ration was affected by the Ca content (Ouanes et al. 2011) and the low blood Ca level after milk sucking period adversely affected the growth and development of lambs (Ataollahia at al. 2018). In this study, the blood Ca levels of the lambs consuming SH were lower than the mean values reported in the literature, however, these values increased independently after common vetch consumption ( $\mathrm{p}<0.05)$. In the literature, it has been reported that the Ca level of CV $(1.08-1.97 \mathrm{~g} / \mathrm{kg}$ $\mathrm{DM}$ ) was lower than the Ca level (12.0 $\left.\mathrm{g} \mathrm{kg}^{-1} \mathrm{DM}\right)$ of SH (Gizachewa and Smit 2005; Scharenberg et al. 2007; Eugeniusz et al. 2010; Uzun et al. 2011; Mao et al. 2015). In this study, despite the low Ca level, it was determined that, after the consumption of $\mathrm{CV}$, the blood $\mathrm{Ca}$ value was not negatively affected and the blood $\mathrm{Ca}$ levels of the lambs were within the normal values. This result was associated with the incomplete rumen development in lambs at the beginning of the experiment.

The blood $\mathrm{P}$ levels of the lambs have been reported in the range of 4-7 $\mathrm{mg} \mathrm{dl}^{-1}$, and when blood $\mathrm{P}$ level was lower than $4 \mathrm{mg} \mathrm{dl}^{-1}$, it was regarded that there was a P deficiency in animals (Pugh and Baird 2012). In this study, the blood $P$ levels at the beginning of the study were found to be close to the upper values reported in the literature (Pugh and Baird 2012). However, after CV consumption, the blood $\mathrm{P}$ values of lambs decreased to normal limits independent of $C V$ consumption $(P<0.05)$. The $P$ value in the structure of $\mathrm{CV}$ (3.50--11.70 $\left.\mathrm{g} \mathrm{kg}^{-1} \mathrm{DM}\right)$ was lower than the $\mathrm{P}$ value $\left(3.44 \mathrm{~g} \mathrm{~kg}^{-1} \mathrm{DM}\right)$ found in the structure of SH (Gizachewa and Smit 2005; Scharenberg et al. 2007; Uzun et al. 2011; Mao et al. 2015). It was thought that the balancing of blood P level in lambs due to CV consumption was caused by the combined effect of both feed mineral structures.

In some studies, normal blood $\mathrm{K}$ levels in lambs have been reported to be in the range of 4.53 to $8.31 \mathrm{mg} \mathrm{dl}^{-1}$ (Bórnez et al. 2009; Denek et al. 2009; Al-dain and Jarjeis 2015). In this study, the blood $\mathrm{K}$ levels of the lambs consuming SH were found to be close to the lower limit reported in the literature, 
and after $\mathrm{CV}$ consumption, it decreased further due to $\mathrm{CV}$ consumption $(\mathrm{P}<0.05)$. This was associated with the fact that the $\mathrm{K}$ value $\left(0.12-1.42 \mathrm{~g} \mathrm{~kg}^{-1} \mathrm{DM}\right)$ present in the $\mathrm{CV}$ was lower than the $\mathrm{K}$ value in the $\mathrm{SH}\left(0.25 \mathrm{~g} \mathrm{~kg}^{-1} \mathrm{DM}\right)$, as also stated in the literature (Gizachewa and Smit 2005; Uzun et al. 2011; Turk et al. 2011).

In some studies, the blood $\mathrm{Cl}$ levels in lambs have been reported as $103.50-119.67 \mathrm{mg} \mathrm{dl}^{-1}$. (Denek et al. 2009; Al-dain and Jarjeis 2015). At the beginning of the study, the blood Cl levels of lambs were close to the lower limit of normal blood $\mathrm{Cl}$ levels, but after the experiment, the blood $\mathrm{Cl}$ levels of the lambs increased in all groups independent of the CV consumption. In the literature, the chlorine content of CV has been reported as $0.50 \mathrm{~g} \mathrm{~kg}^{-1}$ (Riasi et al. 2014; Riasi et al. 2015), while the chlorine content of SH has been reported as $0.32 \mathrm{~g} \mathrm{~kg}^{-1}$ (Xionga et al. 2008). Since the chlorine contents of $\mathrm{CV}$ and $\mathrm{SH}$ were similar, it was thought that the rumen development was caused by the increase in blood $\mathrm{Cl}$ levels of lambs.

Table 4. Pre (A)-and post (B)-research blood sugar (BS), total protein (TP), triglycerides (TG), urea blood urea nitrogen (BUN) blood calcium (Ca), blood potassium (K), blood phosphorus (P), blood chlorine (Cl), blood sodium (Na) (data represents the mean $\pm \mathrm{SEM}$ )

\begin{tabular}{|c|c|c|c|c|c|}
\hline & Time & $\mathrm{C}$ & CVSI & CVSII & $\mathbf{P}<\mathbf{0}$, \\
\hline \multirow[t]{2}{*}{$\overline{\mathrm{BG}\left(\mathrm{mg} \mathrm{dl}^{-1}\right)}$} & $\mathrm{B}$ & $60.75 \pm 5.47$ & $56.37 \pm 2.15$ & $66.25 \pm 4.17$ & ,582567 \\
\hline & A & $66.00 \pm 3.94$ & $57.62 \pm 3.13$ & $66.37 \pm 3.17$ & ,393109 \\
\hline \multirow[t]{2}{*}{$\mathrm{TP}\left(\mathrm{g} \mathrm{dl}^{-1}\right)$} & B & $7.13 \pm 0.16$ & $7.44 \pm 0.32$ & $7.69 \pm 0.16$ &, 542622 \\
\hline & A & $7.25 \pm 0.13$ & $7.65 \pm 0.19$ & $7.65 \pm 0.23$ & ,972842 \\
\hline \multirow[t]{2}{*}{$\mathrm{TG}\left(\mathrm{mg} \mathrm{dl}^{-1}\right)$} & $\mathrm{B}$ & $24.67 \pm 3.42$ & $21.52 \pm 1.52$ & $24.23 \pm 3.05$ & ,266702 \\
\hline & A & $23.93 \pm 2.31$ & $25.40 \pm 2.14$ & $26.43 \pm 4.83$ & ,741169 \\
\hline \multirow[t]{2}{*}{ BUN (mg dl $\left.{ }^{-1}\right)$} & B & $42.83 \pm 1.68 \mathrm{cA}^{*}$ & $56.38 \pm 2.27 \mathrm{bA}^{\#}$ & $63.75 \pm 1.84 \mathrm{aA}$ & ,582567 \\
\hline & A & $44.62 \pm 0.99 \mathrm{aA}$ & $41.00 \pm 2.25 \mathrm{aB}$ & $41.25 \pm 2.29 \mathrm{aB}$ & ,000001 \\
\hline \multirow[t]{2}{*}{$\overline{\text { CALCIM }\left(\mathrm{mg} \mathrm{dl}^{-1}\right)}$} & $\mathrm{B}$ & $9.51 \pm 0.14 \mathrm{~B}$ & $9.80 \pm 0.19 \mathrm{~B}$ & $9.53 \pm 0.23 \mathrm{~B}$ & ,000000 \\
\hline & A & $10.23 \pm 0.08 \mathrm{~A}$ & $10.15 \pm 0.21 \mathrm{~A}$ & $10.24 \pm 0.15 \mathrm{~A}$ &, 000000 \\
\hline \multirow[t]{2}{*}{ PHOSPHORUS $\left(\mathrm{mg} \mathrm{dl}^{-1}\right)$} & B & $8.21 \pm 0.28 \mathrm{~A}$ & $7.51 \pm 0.44 \mathrm{~A}$ & $8.97 \pm 0.57 \mathrm{~A}$ & ,932127 \\
\hline & A & $6.58 \pm 0.39 \mathrm{~B}$ & $6.13 \pm 0.45 B$ & $6.16 \pm 0.44 \mathrm{~B}$ & ,000000 \\
\hline \multirow[t]{2}{*}{ POTASSIUM (mmol dl'-1) } & $\mathrm{B}$ & $5.62 \pm 0.20 \mathrm{~A}$ & $5.04 \pm 0.32 \mathrm{~A}$ & $4.97 \pm 0.16 \mathrm{~A}$ & ,000000 \\
\hline & A & $4.97 \pm 0.18 \mathrm{~A}$ & $4.74 \pm 0.29 B$ & $4.73 \pm 0.12 B$ & ,000000 \\
\hline \multirow[t]{2}{*}{ CHLORINE $\left(\mathrm{mmol} \mathrm{dl}^{-1}\right)$} & $\mathrm{B}$ & $103.75 \pm 0.45 \mathrm{~B}$ & $101.00 \pm 1.63 \mathrm{~B}$ & $101.37 \pm 0.86 \mathrm{~B}$ &, 000000 \\
\hline & A & $108.50 \pm 0.86 \mathrm{~A}$ & $105.00 \pm 2.75 \mathrm{~A}$ & $105.87 \pm 0.58 \mathrm{~A}$ &, 000000 \\
\hline \multirow[t]{2}{*}{ SODIUM (mmol dl $\left.{ }^{-1}\right)$} & B & $145.62 \pm 0.86 \mathrm{~A}$ & $143.00 \pm 1.90 \mathrm{~A}$ & $142.50 \pm 0.90 \mathrm{~B}$ &, 000000 \\
\hline & A & $150.00 \pm 1.21 \mathrm{aA}$ & $142.50 \pm 3.85 \mathrm{bA}$ & $148.12 \pm 0.97 \mathrm{aA}$ &, 000000 \\
\hline
\end{tabular}

* It shows different group means in the same time level (same line) (p <0.05). \#: Different capital letters within the same group (in the same column) show the difference between pre-research and post-research $(\mathrm{p}>0.05)$.

In the literature, the blood $\mathrm{Na}$ levels of lambs have been reported in the range of 142.38-154.09 $\mathrm{mg} \mathrm{dl}^{-1}$ (Bórnez et al. 2009; Al-dain and Jarjeis 2015) and have been reported to be affected by the $\mathrm{Na}$ level of the ration (Vugrovečki et al. 2017). In the present study, Na levels of the lambs in the SHII group were slightly lower than those of the $\mathrm{C}$ and SHI group. This was associated with the individual differences of the animals in the group. However, after CV consumption, this difference disappeared and the blood Na levels of lambs in the CVI and CVII group consuming CV were higher than that of the $\mathrm{C}$ group ( $\mathrm{p}<0.05)$. This increase in $\mathrm{CV}$ consumption was since the $\mathrm{Na}$ level in the structure of $\mathrm{SH}(0.10$ $\left.0.12 \mathrm{~g} \mathrm{~kg}^{-1} \mathrm{DM}\right)$ was lower than the $\mathrm{Na}$ level in the structure of $\mathrm{CV}\left(0.20-1.28 \mathrm{~g} \mathrm{~kg}^{-1} \mathrm{DM}\right)$ (Scharenberg 2007; Xionga et al. 2008; Mao et al. 2015).

It has been reported that rumen $\mathrm{pH}$ was approximately 7 after a normal rumen development in lambs and that rumen flora and fauna were preserved when rumen $\mathrm{pH}$ was in the range of 6.0-6.7 
(Mackie at al. 1978). In one study, it has been reported that the addition of 10, 20 and 30\% common vetch instead of soybean did not change the rumen $\mathrm{pH}$ and the rumen $\mathrm{pH}$ was between 5.28 and 5.45 (Elmal1 et al. 2011). Watson et al. (1984), in a study where they used 100\% lupine instead of wheat, observed no difference in rumen $\mathrm{pH}$, while rumen $\mathrm{pH}$ was 6.05 in the ration where $100 \%$ wheat was used, and 5.08 when $100 \%$ lupine was used. In the present study, it was observed that CV substitution at the $75 \%$ level of SH to rations of lambs consuming SH did not affect the rumen $\mathrm{pH}$ and the rumen $\mathrm{pH}$ was between 6.64 and 6.70. The fact that rumen $\mathrm{pH}$ was higher than the other two studies was associated with the fact that the ration consisted entirely of legumes. Indeed, Wang et al. (2007) have reported that the rumen $\mathrm{pH}$ values changed between 6.34 and 6.44 in sheep consuming legume.

The mean rumen $\mathrm{NH}_{3}-\mathrm{N}$ value or high microbial fermentation has been reported to be $45 \mathrm{mg} / \mathrm{ml}$ (McDonald and Copeland 1997). In animals fed with starch-based rations, the rumen $\mathrm{NH}_{3}-\mathrm{N}$ values decreased (10.12-10.47 mg ml$\left.{ }^{-1}\right)$ whereas the $\mathrm{NH}_{3}-\mathrm{N}$ value $\left(110 \mathrm{mg} \mathrm{ml}^{-1}\right)$ increased in protein-based feeds. In a study where common vetch was used instead of soybeans, no difference was observed between rumen $\mathrm{NH}_{3}-\mathrm{N}$ values, and rumen $\mathrm{NH}_{3}-\mathrm{N}$ value was between 25.12 and $35.15 \mathrm{mg} \mathrm{dL}-1$. In a study using clover and sainfoin hay, rumen $\mathrm{NH}_{3}-\mathrm{N}$ values have been reported to be 36.1 and $27.1 \mathrm{mg} \mathrm{dL}^{-1}$, respectively. The use of $\mathrm{SH}$ in the ration somehow causes $\mathrm{NH}_{3}-\mathrm{N}$ to decrease in the rumen (Wang et al. 2007). In the present study where $\mathrm{CV}$ was added instead of $\mathrm{SH}$, vetch addition increased the rumen $\mathrm{NH}_{3}$ $\mathrm{N}$ value ( $\mathrm{p}>0.05$ ). In a study conducted with oatmeal hay, vetch addition increased the rumen $\mathrm{NH}_{3}-\mathrm{N}$ value (White et al. 2002). This was associated with the fact that high protein CV was not used effectively by rumen microorganisms.

The protozoa counts in lambs increase parallel to a normal rumen development after birth and reaches $10^{4}-10^{6} / \mathrm{ml}$ in the adult period (Kamra 2005). In one study the rumen protozoa counts in sheep consuming SH have been reported as $483.000 \pm 432 / \mathrm{ml}$ (Scharenberg et al. 2007), while in another study, it has been reported that the rumen protozoa counts $(137000 \pm 0.169)$ increased $(173000 \pm 0.169)$ in the case of 50\% SH addition as well as using clover (Wang et al. 2007). In this study, the rumen protozoa count of the lambs consuming SH were lower at the beginning of the experiment, independent of the CV consumption at the end of the trial, and were found to be higher than the values mentioned in some literature $(\mathrm{p}<0.005)$. Although the possible reason for this increase was the rumen development, $\mathrm{CV}$ consumption caused an increase in the protozoa counts, however, this increase was not statistically significant. In the present study, CV consumption did not have a negative effect on rumen protozoa.

Table 5. Pre (A)-and post (B)-research the amount of ammonia, the $\mathrm{pH}$ and the protozoa numbers in rumen liquid (data represents the mean $\pm \mathrm{SEM})$

\begin{tabular}{lcrrrr}
\hline & Time & C & CVSI & CVSII & P<0, \\
\hline Ruminal pH & B & $6.59 \pm 0.04$ & $6.64 \pm 0.06$ & $6.70 \pm 0.10$ &, 413678 \\
& A & $6.68 \pm 0.02$ & $6.61 \pm 0.05$ & $6.55 \pm 0.02$ &, 422045 \\
\hline Protozoa Number, $\left[\mathrm{x} 10^{5} / \mathrm{ml}\right]$ & $\mathrm{B}$ & $1.65690 \pm 0.394 \mathrm{~B} \#$ & $1.79100 \pm 0.342 \mathrm{~B}$ & $1.70730 \pm 0.397 \mathrm{~B}$ &, 235467 \\
& $\mathrm{~A}$ & $3.66550 \pm 0.322 \mathrm{~A}$ & $4.47190 \pm 0.7072 \mathrm{~A}$ & $4.73970 \pm 0.7504 \mathrm{~A}$ &, 000000 \\
\hline Ruminal NH3-N, mg/dL & $\mathrm{B}$ & $24.85 \pm 1.75 \mathrm{~A}$ & $22.36 \pm 2.00 \mathrm{~B}$ & $22.31 \pm 1.63 \mathrm{~B}$ &, 001725 \\
& $\mathrm{~A}$ & $34.62 \pm 4.26 \mathrm{bA}^{*}$ & $67.11 \pm 4.34 \mathrm{aA}$ & $68.91 \pm 9.58 \mathrm{aA}$ &, 000000 \\
\hline
\end{tabular}

* It shows different group means in the same time level (same line) ( $\mathrm{p}<0.05)$. \#: Different capital letters within the same group (in the same column) show the difference between pre-research and post-research $(\mathrm{p}>0.05)$.

\section{CONCLUSION}

In this study, it was found that vetch substitution $(25,50$, and $75 \%)$ instead of sainfoin had no exceeding effect on blood and rumen parameters the limit values reported in the literature for lambs. Giving vetch instead of sainfoin caused a decrease towards lower limit values at blood $\mathrm{K}$ level and an 
increase towards upper limit values at $\mathrm{Na}$ level. The reason for this is thought to be due to $\mathrm{K}$ and $\mathrm{Na}$ in the structure of the vetch. Another result of this study is the vetch seed instead of sainfoin has increased blood $\mathrm{NH}_{3}-\mathrm{N}$, rumen $\mathrm{NH}_{3}-\mathrm{N}$, and rumen $\mathrm{pH}$ to normal upper limit values. The probable cause of this situation is attributed to the fact that the vetch is rich in N. However, further studies are needed on this subject.

\section{REFERENCES}

Abreu M, Bruno-Soares AM, 1998. Chemical composition, organic matter digestibility and gas production of nine legume grains. Animal Feed Science Technology, 70 (1-2): 49-57.

Al-dain QZS, Jarjeis EA, 2015. Evaluation of using some medical herbs seeds as feed additive on some hematological and biochemical parameters for male awassi lambs under local environmental condition of nineveh province, IRAQ. Australian Journal of Basic and Applied Sciences, 9(20): 527-537.

Asharf MY, Asharf M, Öztürk M, 2018. Underutilized vegetabler: A Tool to Address Nutritional Issues, Poverty Rduction and Food Security. Global Perspectives on Underutilized Crops, 1-23.

Ataollahia F, Frienda M. McGratha S. Duttona G. Petersa A. Bhanugopana M. 2018. Effect of calcium and magnesium supplementation on minerals profile, immune responses, and energy profile of ewes and their lambs. Livestock Science 217:167-173

AOAC.1990. Official Methods of Analysis 15t h ed., Association of Official Agricultural Chemists, Washington, D C, 1990.

Aufre`re J, Dudilieu M. Andueza D, Poncet C, Baumont R, 2013. Mixing sainfoin and lucerne to improve the feed value of legumes fed to sheep by the effect of condensed tannins. Animal, 7(1): 82-92.

Bruno-Soares AM, Abreu JMF, Guede CVM, Dias-da-Silva AA, 2000. Chemical composition, DM and NDF degradationkinetics in rumen of seven legume straws. Animal Feed Science and Technology, 83(1-2): 7580.

Bórnez R, Linares MB, Vergara H, 2009. Haematological, hormonal and biochemical blood parameters in lamb: Effect of age and blood sampling time. Livestock Science, 121(2-3): 200-206.

Carbonero CH, Mueller-Harvey I, Terence BA, Smith L., 2011. Sainfoin (Onobrychis viciifolia): A beneficial forage legume. Plant Genetic Resources: Characterization and Utilization, 9(1): 70-85.

Dehority BA, 1984. Evaluation of subsampling and fixation procedures used for counting rumen. Applied and environmental microbiology, 48(1): 182-185

Dejene M. Dixon RM, Duncan AJ, Wolde-meskel E, Walsh KB, McNeill D, 2018. Variations in seed and postharvest residue yields and residues quality of common bean (Phaseolus vulgaris L.) as a ruminant feedstuff. Animal Feed Science and Technology, 244: 42-55.

Denek N, Can A, Tufenk S, Yazgan K, Ipek H, Iriadam M, 2006. The effect of heat load on nutrient utilization and blood parametersof Awassi ram lambs fed different types and levels of forages. Small Ruminant Research, 63: 156-161.

El-Barody MAA, Abdalla EB, Abd El-Hakeam AA, 2002. The changes in some blood metabolites associated with thephysiological responses in sheep. Livestock Production Science, 75(1): 45-50.

Elmalı DA, Ogun M, Merhan O, Kaya I, 2011. The effect of various concentrated feed mixtures on certain blood parameters in tuj lambs. YYU Veteriner Fakultesi Dergisi, 22(3): 153-157.

Eugeniusz R, Rybinski W, Klebaniuk R, Matras J, 2010. Morphological characteristics of some accessions of grass pea (Lathyrus sativus L.) grown in Europe and nutritional traits of their seeds. Genet Resour Crop Evol, $57: 693-701$.

Facciolongo AM, Rubino G, Zarrilli A, Vicenti A, Ragni M, Toteda F, 2014. Alternative protein sources in lamb feeding 1. Effects on productive performances, carcass characteristics and energy and protein metabolism. Progress in Nutrition, 16(2): 105-115. 
Gizachewa L, Smit GN, 2005. Crude protein and mineral composition of majorcrop residues and supplemental feeds produced on Vertisols of the Ethiopian highland. Animal Feed Science and Technology, 119(1-2): 143-153.

Hanbury CD, White CL, Mullan BP, Siddique KHM. 2000. A review of the use and potential of Lathyrus sativus L. and L. cicera L. grain for animal feed. Animal Feed Sci Tech, 87(1-2): 1-27.

Huang YF, Gao XL, Nan ZB, Zhang ZX, 2017. Potential value of the common vetch (Vicia sativaL.) as an animalfeedstuff: a review. Journal of Animal Physiology and Animal Nutrition, 101 (5):807-823.

Kamra DN, 2005. Rumen microbial ecosystem. Special Section: Micrombial Diversitiy. Current Science, 89(1): 124-135.

Kaneko JJ, Kornelius CE, 1970. Clinical biochemistry of domestic animals, 5th edn. Academic Press, New York, USA.

Kohn R.A., Dinneen M.M., Russek-Cohen E., 2005. Using blood urea nitrogen to predict nitrogen excretion and efficiency of nitrogen utilization in cattle, sheep, goats, horses, pigs, and rats. American Society of Animal Science, 83(5): 879-889.

Kobeisy M. Soliman IA. Mohamed SF. Al-Khateeb A. 2017. Effect of dietary addition of lupin and/or fenugreek seeds on thermo-respiratory response and some blood constituents of rahmani sheep. Egyptian J. Anim. Prod. 54(3):185-192.

Lestingi A, Toteda F, Vicenti A, Marzo DD, Facciolongo AM, 2015. the use of faba bean and sweet lupin seeds alone or in combination for growing lambs. 1. Effects on growth performance, carcass traits, and blood parameters. Pakistan J. Zool., vol, 47(4): 989-996.

Mackie, RI. Gilchrist FMC. Robberts AM. Hannah PE. Schwartz HM. 1978. Microbiological and chemical changes in the rumen during the stepwise adaptation of sheep to high concentrate diets. The Journal of Agricultural Science, 90(2), 241-254.

Malekkhahi M, Tahmasbi AM, Naserian AA, Danesh MM, Kleen JL, Parand AA, 2015. Effects of essential oils, yeast culture and malate on rumen fermentation, blood metabolites, growth performance and nutrient digestibility of Baluchi lambs fed highconcentrate diets. J of Anim. Phys. and Anim. Nutr, 99(2): 221-229.

Mao Z, Fu H, Nan Z, Wan C, 2015. Fatty acid, amino acid, and mineral composition of four common vetch seeds on Qinghai-Tibetan plateau. Food Chemistry, 171(15): 13-18.

Markham R, 1942. A steam distilation apparatus suitable for micro-kjheldahl analysis. Biochem. J. 36:790-797.

McDonald NB, Copeland LO, 1997. Part II: Seed production. Practices of Seed Production. SpringerScience+Business Media, M.V. Chapman and Hall Chapnan and Hall, pp. 357. New York.

Mieczan AW, Kwiecien M, 2010. The influence of raw grass pea(lathyrus sativus L.) seeds on growth performance and biochemical and haematological parameters in the blood of grower-finisher pigs. Agricultural and Food Science, 19 :223-232.

Ouanes I. Abdennour C. Aouardjia N. 2011. Effect of cold winter on blood biochemistry of domestic sheep fed natural pasture. Annals of Biological Research, 2(2): 306-313.

Pugh DG, Baird AN, 2012. Sheep and goat medicine. chpter 2. (2nd edition). Elsevier Saunders. 3251 Riverpot Lane Maryland Heights, 63043, pp. 21. Missouri.

Qing-jun S. Ye-hui H. Jian-guo C. 2008. Clinical laboratory 322nd Hospital of PLA Datong Shanxi 037006 China: Maintenance of Reaction Cup for HITACHI 7180 Automatic Biocemical Analyzer.

Riasi A, Golizadeh M, Fathi MH, Asadzadeh N, Taghizadeh AJ, 2014 Determination of the nutritive value of unheated vs. heat processed grass pea seed in ruminants. Agr. Sci. Tech, 16(3): 527-536.

Riasi A, Mahdavi AH, Bayat E, 2015. Effect of different levels of raw and heated grass pea seed (Lathyrus sativus) on nutrient digestibility, intestinal villusmorphology and growth performance of broiler chicks. Journal of Animal Physiology and Animal Nutrition, 99(5): 924-931.

Satter LD, Slyter LL, 1974. Effect of ammonia concentration on rumen microbial protein production in vitro. Br. J. Nutr, 32: 199-208. 
Seifdavati J, Taghizadeh A, 2012. Effects of moist heat treatment on ruminal nutrient degradability of and in vitro intestinal digestibility of crude protein from some of legume seeds. Journal of Food, Agriculture \& Environment, 10(2): 390-397.

Scharenberg A, Arrigo Y, Gutzwiller A, Wyss U, Hess HD, Kreuzer M, Dohme F, 2007. Effect of feeding dehydrated and ensiled tanniferous sainfoin (Onobrychis viciifolia) on nitrogen and mineral digestion and metabolism of lambs. Archives of Animal Nutrition, 6(5): 390-405.

Sheppard SC, Cattani DJ, Ominski KH, Biligetu B, Bittman S, McGeough EJ, 2019. Sainfoin production in western Canada: A review of agronomic potential and environmental benefits. Grass Forage Sci. 74: 6-18.

Sherasia PL, Garg MR, Bhanderi MB, 2017. Pulses and their by-products as animal feed. (Ed. Calles T. and Makkar H.P.S.). Food and Agriculture Organization of the United Nations. pp. 171-172. Rome, Italy.

Turk M, Albayrak S, Tuzun CG, Yuksel O, 2011. Agricultural academy effects of fertilisation and harvesting stages on forage yield and quality of sainfoin (Onobrychis sativa L.). Bulgarian Journal of Agricultural Science, 17(6): 789-794.

Uzun A, Gücer S, Acikgoz E, 2011. Common vetch (vicia sativa 1.) germplasm: correlations of crude protein and mineral content to seed traits. Plant Foods Hum Nutr, 66: 254-260.

Van Soest PJ, Robertson JB, Lewis D, 1991. Methods for diatery fiber, neuteral detergant fiber, and non strach polysaccarides in relatinon to animal nutrition. J. Dairy Sci, 74: 3583-3597.

Vugrovečki AS, Vojta A, Miljenko Š, 2017. Establishing reference intervals for haematological and biochemical blood variables in Lika pramenka sheep. Veterınarskı Arhıv, 87(4): 487-499.

Wang Y, Barbieri LR, Berg P, McAllister TA, 2007. Effects of mixing sainfoin with alfalfa on ensiling, ruminal fermentation and total tractdigestion of silage. Animal Feed Science and Technology, 135(3): 296-314

White CL, Hanbury CD, Young P, Phillips N, Wiese SC, Milton JB, Davidson RH. Siddique KHM, Harris D, 2002. The nutritional value ofLathyrus ciceraandLupinus angustifoliusgrain for sheep. Animal Feed Science and Technology, 99: 45-64.

Wilkinsa RJ, Jones R, 2000. Alternative home-grown protein sources forruminants in the United Kingdom. Animal Feed Science and Technology, 85(1-2): 23-32

Winer BJ, 1971. Statistical principles in experimental design. Mc Grawn Hill Book Company New York. USA. p:907.

Yeheyis L, Tsegahun A, Muchie Y, Bediye S, 2004. Growth performance of yearling menz ram lambs fed on different pulse crop residues. Proceedings of the 12th annual conference of the Ethiopian Society of Animal Production (ESAP) held in Addis Ababa, Ethiopia, Augus, 12(14): 229-232.

Xionga S, Zhanga Q, Zhanga D, Olsson R, 2008. Influence of harvest time on fuel characteristics of five potentialenergy crops in northern China. Bioresource Technology, 99(3): 479-485. 